\title{
Peran Majelis Pengawas Daerah dan Notaris Penerima Protokol Terhadap Penyimpanan Protokol Notaris Yang Telah Berumur 25 Tahun
}

\author{
Dian Ayu Yuhana
}

Magister Hukum Fakultas Hukum Universitas Islam Indonesia Yogyakarta Indonesia Jln. Cik Di Tiro No. 1 Yogyakarta Indonesia dianayu.yuhana@gmail.com

\begin{tabular}{|c|c|}
\hline Key Word: & Abstract \\
\hline $\begin{array}{lr}\text { Notary; } & \text { notary } \\
\text { protocol; } & \text { regional } \\
\text { supervisory council }\end{array}$ & $\begin{array}{l}\text { This study was conducted to analyze the role of the Regional Supervisory Council } \\
\text { for the storage of Notary Protocol that is } 25 \text { years old and to identify the } \\
\text { responsibilities of the Notary Protocol Recipients to the Notary Protocol that is } 25 \\
\text { years old. The formulation of the problems in this research are first, what is the role } \\
\text { of the Regional Supervisory Council on the storage of a Notary Protocol that is } 25 \\
\text { years old? Second, how is the responsibility of the Notary Recipient of the Protocol } \\
\text { to the Notary Protocol who is } 25 \text { years old? This type of research is empirical with a } \\
\text { statutory approach, with juridical analysis. The results of this study conclude that, } \\
\text { firstly, the role of the Regional Supervisory Council has not run properly because it } \\
\text { is constrained by the facilities and infrastructure for storing Notary Protocols, } \\
\text { secondly, the responsibilities of the Notary Recipient of the Protocol to the Notary } \\
\text { Protocol that is } 25 \text { years old that it has received are to store, maintain, and take care } \\
\text { in the way that the Protocols are kept safely that they are not easily damaged and } \\
\text { lost because the Notary Protocol is a state archive that must be safeguarded. }\end{array}$ \\
\hline
\end{tabular}

Kata-kata Kunci:
Majelis pengawas
daerah; notaris;
protokol notaris

\begin{abstract}
Abstrak
Penelitian ini dilakukan untuk menganalisis peran Majelis Pengawas Daerah terhadap penyimpanan Protokol Notaris yang telah berumur 25 tahun aserta mengetahui tanggungjawab dari Notaris Penerima Protokol terhadap Protokol Notaris yang berumur 25 tahun. Rumusan masalah dari penelitian ini, pertama, bagaimana peran Majelis Pengawas Daerah terhadap penyimpanan Protokol Notaris yang berumur 25 tahun? Kedua, bagaimana tanggungjawab Notaris Penerima Protokol terhadap Protokol Notaris yang berumur 25 tahun? Jenis penelitian ini adalah empiris dengan pendekatan perundang-undangan, dengan analisis yuridis. Hasil penelitian ini menyimpulkan, pertama, peran Majelis Pengawas Daerah belum berjalan sebagaimana mestinya karena terkendala sarana dan prasarana penyimpanan Protokol Notaris, kedua tanggungjawab Notaris Penerima Protokol terhadap Protokol Notaris yang berumur 25 tahun yang telah diterimanya yaitu menyimpan, menjaga, dan merawat agar Protokol-Protokol tersebut tetap tersimpan dengan aman agar tidak mudah rusak dan hilang karena Protokol Notaris merupakan arsip negara yang harus tetap ada.
\end{abstract}

\section{Pendahuluan}

Kepastian, ketertiban dan perlindungan hukum dalam lalu lintas hukum pada umumnya memerlukan alat bukti yang menentukan dengan jelas hak dan kewajiban seseorang sebagai subyek hukum dalam masyarakat. Sistem hukum yang berlaku di Indonesia khususnya dalam masalah perdata lebih mengenal dan menentukan adanya 
pembuktian tertulis, ${ }^{1}$ sehingga bukti tulisan memiliki kekuatan pembuktian lebih tinggi. Pembuktian dengan alat bukti tulisan dapat berupa akta otentik atau akta di bawah tangan, dimana akta otentik berkedudukan sebagai alat bukti yang sempurna atau alat bukti yang terkuat. ${ }^{2}$ Akta otentik adalah tulisan yang dibuat dalam bentuk yang ditetapkan undang-undang, dibuat oleh atau di hadapan pejabat umum yang berwenang untuk itu di tempat dimana akta itu dibuat. ${ }^{3}$ Hal ini memberikan pengertian bahwa Notaris diberikan kewenangan oleh undang-undang untuk menciptakan alat pembuktian yang mutlak, dalam pengertian bahwa apa yang tersebut dalam akta otentik itu pada pokoknya dianggap benar. ${ }^{4}$ Pentingnya peranan Notaris dalam membantu menciptakan kepastian dan perlindungan masyarakat memiliki sifat preventif, atau bersifat pencegahan atas terjadinya masalah hukum. Pencegahan permasalahan hukum tersebut dilakukan dengan cara penerbitan akta otentik yang dibuat di hadapannya terkait dengan status hukum, hak dan kewajiban seseorang dalam hukum, dan lain sebagainya, yang berfungsi sebagai alat butki yang paling sempurna di Pengadilan, dalam hal terjadi sengketa hak dan kewajiban yang terkait. ${ }^{5}$

Keberadaan Notaris dalam menjalankan kewenangan menjadi penting bagi masyarakat maupun negara. Kewenangan notaris dalam membuat akta otentik maupun akta lainnya tidak dapat dilakukan oleh pejabat atau profesi hukum lain, sehingga dalam menjalankan profesinya Notaris dituntut untuk bekerja secara benar dan professional. Notaris dalam menjalankan jabatannya, salah satu kewajiban Notaris adalah membuat akta dalam bentuk minuta akta dan menyimpannya sebagai bagian dari Protokol Notaris, sebagaimana diatur dalam Pasal 16 ayat (1) huruf b Undang-Undang Nomor 2 Tahun 2014 tentang Perubahan Atas Undang-Undang Nomor 30 Tahun 2004 tentang Jabatan Notaris (UUJN-P). Pada penjelasan Pasal tersebut, dijelaskan bahwa kewajiban dalam menyimpan minuta akta sebagai bagian dari Protokol Notaris, dimaksudkan untuk menjaga keontetikan suatu akta dengan menyimpan akta dalam bentuk aslinya, sehingga apabila ada Notaris yang purnabakti atau meninggal dunia tetap disimpan melalui Protokol Notaris. 6

Protokol Notaris wajib dirawat dan disimpan dengan baik oleh Notaris yang bersangkutan karena Protokol Notaris akan tetap berlaku sepanjang jabatan Notaris masih tetap diperlukan oleh Negara. ${ }^{7}$ Akta Notaris dalam bentuk Salinan akan selamanya ada jika disimpan oleh yang bersangkutan, dan dalam bentuk Minuta juga akan selamanya ada jika disimpan oleh Notaris itu sendiri atau oleh Notaris Penerima Protokol atau oleh Majelis Pengawas Daerah (MPD). Ketika calon Notaris akan diangkat sebagai Notaris, akan diminta apakah bersedia menerima Protokol Notaris lain. Hal ini sudah menjadi kewajiban hukum untuk menerimanya. Ketika seorang Notaris pensiun

${ }^{1}$ Pasal 1866 Kitab Undang-Undang Hukum Perdata.

${ }^{2}$ Habib Adjie dan Rusdianto Sesung (1), Tafsir, Penjelasan dan Komentar Atas Undang-Undang Jabatan Notaris, PT. Refika Aditama, Bandung, 2020, hlm. 3.

${ }^{3}$ Pasal 1868 Kitab Undang-Undang Hukum Perdata.

${ }^{4}$ R. Soegondo Notodisoerjo, Hukum Notariat di Indonesia Suatu Penjelasan, PT. Raja Grafindo Persada, Jakarta, 1982, hlm. 8.

5 Sjaifurrachman \& Habib Adjie, Op. Cit.

${ }^{6}$ Amsyah, Zulkifli, Manajemen Kearsipan, Gramedia Pustaka Utama, Jakarta, 2005, hlm. 117.

${ }^{7}$ Habib Adjie dan Rusdianto Sesung (1), Op. Cit, hlm. 512. 
atau berhenti dari jabatannya sebagai Notaris, maka Akta Notaris tersebut harus dipegang atau disimpan oleh Notaris lainnya sebagai Penerima Protokol Notaris, dan Penerima Protokol Notaris tersebut tidak dapat melakukan perubahan atas isi akta. Tugas seorang Notaris Penerima Protokol adalah merawat dan mengeluarkan salinan atas permintaan para pihak yang bersangkutan dengan akta atau ahli warisnya sebagai suatu upaya untuk menjaga umur yuridis Akta Notaris sebagai alat butki yang sempurna bagi para pihak atau ahli warisnya tentang segala hal yang termuat di dalam akta tersebut. ${ }^{8}$

Pertanggungjawaban protokol tersebut disebutkan dalam Pasal 65 UUJN-P yang menyebutkan: "Notaris, Notaris pengganti dan Pejabat sementara notaris bertanggung jawab atas setiap akta yang dibuatnya, meskipun Protokol Notaris telah diserahkan atau dipindahkan kepada pihak penyimpan Protokol Notaris." Dalam Pasal 62 UUJN, penyerahan Protokol Notaris dilakukan dalam hal Notaris: a) meninggal dunia; b) telah berakhir masa jabatannya; c) minta sendiri; d) tidak mampu secara rohani dan/atau jasmani untuk melaksanakan tugas jabatan sebagai Notaris secara terus menerus lebih dari 3 tahun; e) diangkat menjadi pejabat Negara; f) pindah wilayah jabatn; g) diberhentika sementara; atau h) diberhentikan dengan tidak hormat. Perihal dengan penyerahan Protokol Notaris dilakukan paling lambat 30 hari dengan membuat berita acara penyerahan. ${ }^{9}$ Protokol Notaris yang telah berusia 25 tahun atau lebih diserah terimakan oleh Notaris yang menerima protokol dari Notaris lain kepada MPD. ${ }^{10}$ Penyimpanan arsip penting negara (Protokol Notaris), tentunya harus selalu memperhatikan faktor keamanan protokol tersebut dari risiko kerusakan, dengan cara seksama dan penuh kehati-hatian perlu dijaga agar tidak rusak, sobek, tercecer, rusak karena usia atau dimakan serangga, atau bahkan hilang.

Menjadi kewajiban bagi pejabat umum (Notaris) setelah itu adalah menyimpan protokol tersebut, untuk protokol yang minimal sudah berusia 25 tahun atau lebih diserahkan ke MPD untuk disimpan. ${ }^{11}$ Dalam hal penyimpanan Protokol Notaris yang berumur 25 tahun atau lebih ini menimbulkan persoalan tersendiri dalam hal penyimpanannya. Dalam kurun waktu minimal 25 tahun bukanlah waktu yang sebentar, dalam waktu yang begitu lamanya sudah berapa ratus bahkan mungkin mencapai ribuan hanya dari 1 Notaris saja. Padahal dalam satu wilayah biasanya ada lebih dari satu Notaris, sehingga jumlah Protokol Notaris yang banyak dan harus diserahkan kepada MPD.

Berdasarkan penelitian yang telah penulis lakukan dari hasil wawancara dengan salah seorang Notaris di wilayah Jawa Tengah, bahwa Notaris tersebut sampai sekarang masih menyimpan Protokol Notaris di kantornya, bahkan ada Protokol Notaris yang usianya lebih dari 25 tahun yang masih tersimpan dan belum diserahkan ke Notaris Penerima Protokol dan juga MPD. Seperti yang disebutkan dalam Pasal 63 ayat (5) apabila Protokol Notaris tidak diserahkan kepada MPD, maka MPD berwenang mengambil Protokol Notaris tersebut, tetapi sampai saat ini belum ada MPD yang

${ }^{8}$ Ibid., hlm. 521.

${ }^{9}$ Lihat Pasal 63 ayat (1) Undang-Undang Nomor 30 Tahun 2004 tentang Jabatan Notaris

${ }^{10}$ Lihat Pasal 63 ayat (5) Undang-Undang Nomor 30 Tahun 2004 tentang Jabatan Notaris

11 Hery Sunaryanto, "Efektivitas Tempat Penyimpanan Protokol Notaris Yang Telah Berumur 25 Tahun”, Jurnal Hukum dan Kenotariatan, Vol. 2 No. 2, Malang, 2018, hlm. 292 
mengambil Protokol Notaris sehingga Protokol Notaris tersebut masih tersimpan di kantornya. Hal ini dikarenakan MPD yang tidak mampu menyimpan Protokol Notaris yang jumlahnya banyak di kantor MPD karena Majelis Pengawas itu sendiri tidak memiliki kantor untuk menyimpan dokumen-dokumen tersebut, sehingga protokolProtokol Notaris tersebut masih tersimpan di kantor Notaris yang bersangkutan. Artinya, ketentuan Pasal 63 ayat (5) UUJN-P tak dapat dijalankan sebagaimana mestinya. ${ }^{12}$ Dengan adanya keterbatasan tersebut maka MPD menyerahkan dokumen-dokumen tersebut kepada Notaris Penerima Protokol. Bahkan tidak sedikit Notaris-Notaris yang masih menyimpan Protokol Notaris di kantor Notaris yang bersangkutan tersebut. Persoalan ini pun semakin diperkuat dengan tidak ada solusi dari UUJN itu sendiri dan tidak ada juga undang-undang yang mengatur secara tegas tentang apa sanksi yang diberikan apabila Pasal 63 ayat (5) ini tidak dilaksanakan.

\section{Rumusan Masalah}

Berdasarkan penjelasan di atas, maka rumusan masalah yang diambil adalah pertama, bagaimana peran Majelis Pengawas Notaris terhadap penyimpanan Protokol Notaris yang berumur 25 tahun? Kedua, bagaimana tanggungjawab Notaris Penerima Protokol Notaris terhadap Protokol Notaris yang berumur 25 Tahun?

\section{Tujuan Penelitian}

Tujuan diadakan penelitian ini adalah untuk mengetahui, mengkaji, menganalisis dan memperoleh pengetahuan mengenai peran Majelis Pengawas Daerah (MPD) dalam penyimpanan Protokol Notaris yang usianya sudah 25 tahun atau lebih, serta mengetahui bagaimana tanggungjawab seorang Notaris Penerima Protokol terhadap Protokol Notaris yang diterimanya.

\section{Metode Penelitian}

Jenis penelitian yang dilakukan adalah dengan cara penelitian secara hukum Empiris. Metode pendekatan yang digunakan adalah pendekatan perundang-undangan. Penelitian ini diperoleh dari berbagai sumber, yaitu data primer dan data sekunder, metode pengumpulan data dilakukan dengan studi pustaka dan wawancara, teknik analisis data dengan menggunakan analisis yuridis.

\section{Hasil Penelitian dan Pembahasan}

\section{Peran Majelis Pengawas Notaris Terhadap Penyimpanan Protokol Notaris yang Berumur 25 Tahun}

Notaris dalam menjalankan jabatannya selain memiliki kewenangan untuk membuat akta otentik, Notaris juga memiliki kewajiban yang salah satunya adalah membuat akta dalam bentuk minuta akta dan menyimpannya sebagai bagian dari

12 Mohamat Riza Kuswanto, "Urgensi Penyimpanan Protokol Notaris Dalam Bentuk Elektronik Dan Kepastian Hukumnya Di Indonesia”, Jurnal Repertorium Vol. IV. No. 2. Surakarta, 2017, hlm. 65. 
Protokol Notaris. Hal tersebut telah diatur dalam Pasal 16 ayat (1) huruf b UUJN-P. Kewajiban penyimpanan ini tidak hanya berlaku terhadap minuta akta yang dibuat oleh dan/atau dihadapan Notaris, tetapi juga berlaku terhadap Protokol Notaris lain yang diterimanya baik karena Notaris lain tersebut meninggal dunia, telah berakhir masa jabatan, ataupun sebab lainnya sebagaimana diatur dalam Pasal 62 UUJN. ${ }^{13}$ Proses penyimpanan Protokol Notaris perlu dilakukan dengan kehati-hatian, agar Protokol Notaris tersebut tidak tercecer, hilang atau rusak. ${ }^{14}$

Notaris dalam menjalankan tugas dan jabatannya memiliki batas masa jabatan/pesiun, dimana masa jabatan ini berakhir pada saat Notaris berumur 65 tahun, dan dapat diperpanjang hingga umur 67 tahun. Berakhirnya masa jabatan ini sejalan dengan berpindahnya kumpulan dokumen-dokumen yang merupakan arsip negara. Notaris yang memasuki masa pensiun, wajib memberitahukan kepada MPD setempat mengenai berakhirnya masa jabatan. Pemberitahuan tersebut dimaksudkan sebab Notaris yang pensiun harus menyerahkan Protokol-Protokol Notaris kepada Notaris Penerima Protokol Notaris yang kemudian di serahkan kepada MPD, untuk disimpan di tempat yang telah ditentukan.

Penyimpanan Protokol ini sejalan dengan Pasal 70 huruf e UUJN yang menyatakan bahwa "menentukan tempat penyimpanan protokol Notaris yang pada saat serah terima protokol Notaris telah berumur 25 (dua puluh lima) tahun atau lebih". Selain itu juga koheren dengan Pasal 23 ayat (1) huruf c Permenkumham No 40 Tahun 2015 bahwa "Menerima dan menentukan tempat penyimpanan Protokol Notaris yang pada saat serah terima Protokol Notaris telah berumur 25 (dua puluh lima) tahun atau lebih". Penyimpanan Protokol Notaris oleh Notaris Penerima Protokol merupakan suatu upaya untuk menjaga keontetikan akta Notaris sebagai alat bukti yang sempurna bagi para pihak atau ahli warisnya tentang segala hal yang termuat di dalam akta tersebut. Akta Notaris dalam bentuk salinan akan selamanya ada jika disimpan oleh yang bersangkutan dan dalam bentuk minuta juga akan selamanya disimpan oleh Notaris sendiri atau Notaris Penerima Protokol atau oleh MPD. 15

Pelaksanaan penyimpanan Protokol Notaris berdasarkan pendapat dari MPD Kota Yogyakarta, menjelaskan bahwa penyimpanan Protokol Notaris yang berumur 25 tahun sebagaimana yang dimaksud dalam Pasal 63 UUJN belum terlaksana sampai saat ini. Permasalahan ini menurut MPD Kota Yogyakarta terjadi tidak hanya di Kota Yogyakarta, tetapi di seluruh Indonesia, yang menjadi faktor tidak terlaksananya Pasal 63 UUJN ini karena tidak adanya tempat penyimpanan atau kantor yang memadai untuk penyimpanan Protokol-Protokol Notaris tersebut. ${ }^{16}$ Sama halnya dengan penyimpanan Protokol Notaris berdasarkan pendapat MPD di Kabupaten Bantul, menurutnya peran MPD terhadap penyimpanan Prtokol Notaris yang berumur 25 tahun sampai saat ini

${ }^{13}$ Cut Era Fitriyeni, “Tanggung Jawab Notaris Terhadap Penyimpanan Minuta Akta Sebagai Bagian Dari Prokol Notaris”, Kanun Jurnal Hukum, No 58, Desember 2010, hlm. 396.

${ }^{14}$ Mohammad Rizka Kuswanto, "Urgensi Penyimpanan Protokol Notaris Dalam Bentuk Elektronik Dan Kepastian Hukumnya Di Indonesia”, Vol. IV, No. 2 Juli-Desember 2017, hlm. 63.

15 Brinda Anitha Wirastuti, "Akibat Hukum Protokol Notaris Yang Tidak Diserahkan Oleh Ahli Waris Kepada Notaris Lain”, Jurnal Al-Qanun, Vol. 20, No .2, Desember 2017, hlm. 269.

${ }^{16}$ Hasil Wawancara dengan H. Muhammad Firdauz I.P., selaku Notaris dan Majelis Pengawas Daerah Kota Yogyakarta, pada 1 September 2020, pukul 10.00 WIB. 
belum terlaksana karena terkendala sarana prasaranan untuk penyimpanan Protokol Notaris. ${ }^{17}$ Begitu pula dengan penyimpanan Protokol Notaris yang berumur 25 tahun di Kabupaten Sleman belum terlaksana. Berdasarkan pendapat dari MPD Sleman, mengatakan selama menjabat masih belum bisa menerima penyimpanan Protokol Notaris, karena tidak adanya tempat untuk penyimpanan. Sehingga peran dari MPD belum bisa terlaksana. ${ }^{18}$

\section{Tanggungjawab Notaris Penerima Protokol Notaris terhadap Protokol Notaris yang Berumur 25 Tahun}

Penyimpanan Protokol Notaris yang berumur 25 tahun atau lebih itu diserahkan oleh Notaris Penerima Protokol kepada MPD, yang nantinya disimpan oleh MPD sebagai arsip negara, karena sebenarnya Protokol Notaris itu merupakan milik negara. Namun faktanya belum ada Protokol-Protokol tersebut yang diserahkan kepada MPD sampai saat ini, dan hal tersebut merupakan masalah Nasional yang artinya terjadi di wilayah Indonesia karena tidak adanya sarana dan prasarana. Walaupun Undang-Undang mengatakan bahwa Protokol Notaris yang berumur 25 tahun itu diserahkan pada MPD, tetapi fakta di lapangannya tidak dapat berjalan sebagaimana yang diatur di dalam peraturan perundang-undangan. Hal ini membuat kebingungan dan kewalahan bagi para MPD dalam menghadapi permasalahan penyimpanan Protokol-Protokol tersebut karena pada dasarnya regulasi itu selalu tertinggal, regulasi tidak mengatur sampai sejauh itu, padahal kenyataannya di lapangan tidak semudah seperti yang ditulis di regulasi. ${ }^{19}$

Selain penjelasan dari Notaris dan MPD, Kantor Wilayah Kementerian Hukum dan Hak Asasi Manusia Daerah Istimewa Yogyakarta (Kanwil DIY) juga menjelaskan bahwa belum pernah menerima Protokol Notaris yang berumur 25 tahun untuk saat ini. Protokol-Protokol tersebut masih tersimpan di Notaris yang bersangkutan kalau Notarisnya belum pensiun, kalau sudah pensiun akan disimpan di Notaris Penerima Protokol. Kendala dari permasalahan ini yaitu, tidak adanya sarana dan prasarana karena keterbatasan anggaran. Upaya dari Kanwil DIY terkait permasalahan ini yaitu sudah adanya komunikasi dengan pemerintah pusat untuk membangun gedung guna dijadikan gudang arsip/tempat penyimpanan khusus untuk Protokol-Protokol Notaris. ${ }^{20}$ Berdasarkan hal tersebut di atas dapat dilihat bahwa UUJN telah melimpahkan kewenangan kepada MPD untuk menerima, menyimpan dan menentukan tempat penyimpanan dari Protokol Notaris yang sudah berumur 25 tahun, namun dalam prakteknya yang terjadi, MPD belum bisa melaksanakan kewenangan yang diberikan UUJN. Sampai saat ini, permasalahan ini tidak hanya terjadi di Daerah Istimewa Yogyakarta bahkan seluruh Indonesia, sehingga peran MPD dalam penyimpanan

17 Hasil Wawancara dengan Edi Minarso, selaku Notaris dan Majelis Pengawas Daerah Kabupaten Bantul, pada 8 Oktober 2020, Pukul 10.20 WIB.

${ }_{18}$ Hasil Wawancara dengan Hitaprana, selaku Notaris dan Majelis Pengawas Daerah Kabupaten Sleman, pada 4 November 2020, Pukul 10.30 WIB.

${ }_{19}$ Hasil wawancara dengan Mulyoto, selaku Notaris di Boyolali Jawa Tengah, pada 20 Oktober 2020, pukul 14.00 WIB.

${ }^{20}$ Hasil wawancara dengan Vani selaku Majelis Pengawas Daerah Kementerian Hukum dan Hak Asasi Manusia Daerah Istimewa Yogyakarta, pada 9 November 2020, pukul 10.00 WIB. 
Protokol Notaris yang berumur 25 tahun ini belum dapat terlaksana karena tidak adanya sarana dan prasarana.

\section{Tanggungjawab Notaris Penerima Protokol Notaris terhadap Protokol Notaris yang Berumur 25 Tahun}

Selain MPD yang mempunyai wewenang dan tanggungjawab terhadap Protokol Notaris yang berumur 25 tahun, Notaris Penerima Protokol juga mempunyai tanggungjawab terhadap Protokol Notaris yang berumur 25 tahun. Notaris dalam menjalankan jabatannya memiliki tanggungjawab untuk selalu patuh dan taat kepada peraturan perundang-undangan yang berlaku sebagaimana terucap dalam sumpah jabatannya: "bahwa saya akan patuh dan setia kepada Negara Republik Indonesia, Pancasila dan Undang-Undang Dasar Negara Republik Indonesia Tahun 1945, UndangUndang tentang Jabatan Notaris serta peraturan perundang-undangan lainnya." Berkaitan dengan tanggungjawab, Notaris dalam menjalankan Jabatannya mempunyai tanggungjawab seperti, tanggungjawab terhadap Protokol Notaris. Notaris diwajibkan untuk menjaga Protokol Notaris karena merupakan arsip Negara, ${ }^{21}$ dan Notaris pada saat disumpah menjadi Notaris, Notaris harus bersedia menerima Protokol Notaris dari Notaris lain, seperti Protokol yang sudah berumur 25 Tahun.

Tanggungjawab Notaris sebagai pejabat umum meliputi tanggungjawab profesi Notaris itu sendiri yang berhubungan dengan akta, diantaranya: Pertama, tanggungjawab Notaris secara perdata atas akta yang dibuatnya. Tanggungjawab dalam hal ini adalah tanggungjawab terhadap kebenaran materiil akta, dalam konstruksi perbuatan melawan hukum. Perbuatan melawan hukum disini dalam sifat aktif maupun pasif. Aktif artinya melakukan perbuatan yang menimbulkan kerugian pada pihak lain. Sedangkan pasif yaitu tidak melakukan perbuatan yang merupakan keharusan, sehingga pihak lain menderita kerugian. Jadi unsur dari perbuatan melawan hukum disini yaitu adanya perbuatan melawan hukum, adanya kesalahan dan adanya kerugian yang ditimbulkan. Kedua, tanggungjawab Notaris secara pidana atas akta yang dibuatnya. Pidana dalam hal ini adalah perbuatan pidana yang dilakukan oleh seorang Notaris dalam kapasitasnya sebagai pejabat umum yang berwenang membuat akta, bukan dalam konteks individu sebagai warga negara pada umumnya. Ketiga, tanggungjawab Notaris secara administrasi atas akta yang dibuatnya. Sanksi administrasi berdasarkan UUJN menyebutkan ada 5 (lima) jenis sanksi administrasi yang diberikan apabila seorang Notaris melanggar, yaitu dengan peringatan tertulis, pemberhentian sementara, pemberhentian dengan hormat, dan pemberhentian dengan tidak hormat.22 Oleh karena itu kewajiban Notaris dalam bidang administrasi adalah menyimpan dan memelihara segala dokumen termasuk diantaranya kumpulan akta dan berbagai dokumen lainnya yang dikenal dengan Protokol Notaris. Protokol Notaris merupakan arsip negara, maka dari itu Protokol

${ }^{21}$ Hatta Isnaini Wahyu Utomo, Imam, Safi'I, “Tanggungjawab Mantan Karyawan Notaris sebagai Saksi Akta Terhadap Kerahasiaan Akta", Jurnala Res Judicata, Vol. 2, No. 2, 2019, hlm. 215.

22 Melita Trisnawati, Suteki, "Perlindungan Hukum Terhadap Notaris Penerima Protokol Dalam Hal Terjadi Pelanggaran Akta Notaris Oleh Notaris Pemberi Protokol Yang Telah Meninggal”, Jurnal Notarius, Vol. 12, No. 1, Semarang, 2019, hlm. 30. 
Notaris harus diperlakukan seperti dokumen negara yang harus disimpan dan dijaga agar tetap otentik. Dengan demikian Protokol Notaris sebagai kumpulan dokumen harus selalu disimpan dan dipelihara dalam keadaan apapun meskipun Notaris pemilik Protokol yang pensiun maupun telah meninggal dunia.

Tanggungjawab Notaris untuk menjaga Protokol Notaris tidak hanya sebatas Protokol atas akta-akta yang dibuatnya sendiri tetapi juga atas Protokol yang diterimanya dari Notaris lain. Selain itu tanggungjawab Notaris untuk menjaga Protokol juga tidak hanya sebatas menjaga secara fisik saja tetapi juga menjaga kerahasiaan yang terdapat di dalamnya sebagaimana diucapkan dalam sumpah jabatan yaitu "bahwa saya akan merahasiakan isi akta dan keterangan yang diperoleh dalam pelaksanaan jabatan saya" dan juga menjadi kewajiban sebagaimana diatur dalam Pasal 16 ayat (1) butir f UUJN yang mewajibkan Notaris merahasiakan segala sesuatu mengenai akta yang dibuatnya dan segala keterangan yang diperoleh guna pembuatan akta sesuai dengan sumpah/janji jabatan, kecuali undang-undang menentukan lain.

Notaris Bimo Seno Sanjaya sebagai Notaris Penerima Protokol mengatakan bahwa Notaris Bimo memiliki kewajiban untuk menyerahkan Protokol-Protokol Notaris yang beurmur 25 tahun yang diterimanya kepada MPD, tetapi nyatanya MPD belum siap untuk menerima Protokol Notaris tersebut karena tidak adanya tempat penyimpanan. Sehingga hal tersebut masih menjadi tanggungjawab bagi Notaris Bimo Seno Sanjaya karena sebagai Notaris Penerima Protokol dari Notaris lain yang diterimanya. Tanggungjawab Notaris Bimo Seno Sanjaya sebagai Notaris Penerima Protokol lain yaitu merawat, menyimpan dengan baik sebagaimana Protokolnya sendiri, sehingga suatu saat apabila ada klien yang membutuhkan Protokol tersebut dapat menemuinya selaku Notaris Penerima Protokol. ${ }^{23}$ Pada saat serah terima Protokol Notaris dari Notaris lain, penyerahan bundel minuta akta yang merupakan bagian dari Protokol Notaris diperiksa kelengkapannya, nomor-nomor dan warkah-warkahnya satu persatu dicocokkan, dan apakah sudah lengkap atau belum sesuai dengan Berita Acara Serah Terima Protokol Notaris bahwa Protokol Notaris yang diserahkan dan diterima telah sesuai dengan isi yang termuat dalam berita acara tersebut. ${ }^{24}$

Sama halnya dengan Notaris Hendrik Budi Untung mengatakan bahwa Protokol Notaris yang diterimanya sudah ada yang berumur 25 tahun dan masih tersimpan di kantornya. Menurut Budi Untung, menyimpan dan merawat Protokol Notaris yang ada padanya merupakan tanggungjawab Budi Untung sebagai Notaris Penerima Protokol Notaris. Hal ini dikarenakan MPD belum siap dan belum mampu untuk menerima Protokol-Protokol Notaris, sehingga Notaris Penerima Protokol harus siap akan hal tersebut. Notaris Penerima Protokol harus mempunyai tempat yang baik dan mencukupi untuk menyimpan Protokol-Protokol Notaris yang diterimanya karena akan disimpan di kantornya selama MPD belum mempunyai tempat untuk penyimpanan. ${ }^{25}$

${ }^{23}$ Hasil wawancara dengan Bimo Seno Sanjaya, selaku Notaris Kota Yogyakarta, pada 26 Oktober 2020, pukul 15.00 WIB.

24 Ibid.

${ }^{25}$ Hasil wawancara dengan Hendrik Budi Untung, selaku Notaris di Kota Yogyakarta, pada 4 November 2020, pukul 09.00 WIB 
Pendapat yang sama juga dikemukakan oleh Notaris Jenny Setiawati, Notaris Penerima Protokol harus bertanggungjawab atas Protokol Notaris yang telah diserahkan kepadanya. Notaris Penerima Protokol wajib merawat dan menjaga Protokol Notaris seperti merawat dan menjaga Protokolnya sendiri. Notaris Penerima Protokol apabila dalam menjaga Protokol Notaris yang diserahkan kepadanya menjadi rusak atau hilang maka Notaris Penerima Protokol harus bertanggungjawab atas hal tersebut. Dalam hal ini Notaris Penerima Protokol dapat bertanggungjawab secara pidana atas apa yang telah terjadi terhadap Protokol Notaris yang diserahkan kepadanya. Hal ini dikarenakan Notaris Penerima Protokol dianggap telah lalai dan tidak berhati-hati dalam menjalankan tanggungjawabnya sebagai Notaris Penerima Protokol Notaris. ${ }^{26}$

Hal yang sama juga dikemukakan oleh Notaris Dyah Maryulina Budi Mumpuni bahwa sebagai Notaris Penerima Protokol harus menyimpan, merawat dan bertanggungjawab atas Protokol-Protokol yang diterimanya sesuai berita acara penyerahan Protokol Notaris. Notaris Penerima Protokol dapat dimintai pertanggungjawaban Protokol-Protokol yang diterimanya. Oleh karena itu, Notaris Penerima Protokol harus lebih cermat, teliti dan hati-hati terhdap Protokol Notaris yang diterimanya. ${ }^{27}$

Pendapat dari Notaris Mustafa mengatakan bahwa Notaris Penerima Protokol bertanggungjawab terhadap Protokol yang diterimanya yaitu menyimpan, merawat agar tidak rusak dan hilang. Sedangkan Protokol Notaris yang berumur 25 tahun Notaris Penerima Protokol sudah tidak bertanggungjawab lagi terhadap Protokol Notaris yang berumur 25 tahun walaupun Protokol Notaris tersebut masih tersimpan di kantor Notaris Penerima Protokol, karena hal tersebut merupakan tanggungjawab dan kewenangan dari MPD. ${ }^{28}$ Undang-Undang tidak hanya mengatur cara penyimpanannya, tapi juga mengatur tempat penyimpanannya. Tempat penyimpanan yang dimaksud itu harus rapih dan aman agar Protokol Notaris tidak mudah rusak dan hilang. Akta- akta, reportorium, dan lain-lainnya itu harus diamankan dari kerusakan yang disebabkan karena terjadinya kebakaran dan pengaruh-pengaruh lainnya dari luar, misalnya seperti lembab dan binatang-binatang contohnya rayap yang dapat merusaknya dan juga terhadap pencurian. Walaupun undang-undang sendiri tidak menyebutkan hal diatas, Notaris harus mempunyai inisiatif tersebut, agar Protokol-Protokol Notaris terjamin keamanannya. Protokol Notaris yang diatur dalam undang-undang tersebut merupakan arsip negara yang sangat penting, yang harus dipelihara dan dijaga oleh Notaris karena merupakan alat bukti yang sah dan kuat apabila kelak dikemudian hari terjadi permasalahan diantara para pihak dalam suatu akta.

Berdasarkan penelitian yang dilakukan mengenai tanggungjawab Notaris Penerima Protokol terhadap Protokol Notaris berumur 25 tahun yang telah diterimanya yaitu menyimpan, menjaga, dan merawat agar Protokol-Protokol tersebut tetap

${ }^{26}$ Hasil wawancara dengan MF Jenny Setiawati, selaku Notaris di Kota Yogyakarta, pada 11 November 2020, pukul 12.00 WIB.

27 Hasil wawancara dengan Dyah Mayulina Budi Mumpuni, selaku Notaris di Kota Yogyakarta, pada 24 November 2020, pukul 12.40 WIB.

${ }_{28}$ Hasil wawancara dengan Mustafa, selaku Notaris Kota Yogyakarta, pada 4 November 2020, pukul $11.30 \mathrm{WIB}$. 
tersimpan dengan aman agar tidak mudah rusak dan hilang karena Protokol Notaris merupakan arsip negara yang harus tetap ada walaupun Notaris yang bersangkutan sudah tidak menjabat lagi. Hal ini dilakukan karena apabila dikemudian hari para pihak menanyakan kembali perihal aktanya tersebut yang akan dijadikan alat pembuktian, maka akta tersebut masih ada. Sehingga Notaris Penerima Protokol wajib menjalankan tanggungjawabnya dengan baik dan benar, kerena apabila Protokol Notaris yang dipegang/disimpannya mengalami kerusakan atau kehilangan akibat kelalaiannya, maka Notaris Penerima Protokol harus bertanggungjawab terhadap protokol tersebut dimana Notaris dapat dituntut secara pidana.

\section{Penutup}

Berdasarkan Pasal 63 ayat (5) dan (6) jo. Pasal 70 huruf e UUJN mengenai tempat penyimpanan Protokol Notaris yang berumur 25 tahun oleh MPD sampai saat ini belum berjalan sebagaimana mestinya, permasalahan ini tidak hanya terjadi di Kota Yogyakarta saja namun sewilayah Daerah Istimewa Yogyakarta belum dapat menjalan aturan dari UUJN tersebut. MPD belum bisa melaksanakan kewenangan yang diberikan UUJN tersebut karena tidak adanya sarana dan prasarana untuk penyimpanan ProtokolProtokol Notaris, serta belum adanya anggaran khusus mengenai hal ini. Tanggungjawab Notaris Penerima Protokol terhadap Protokol Notaris yang berumur 25 tahun yang telah diterimanya yaitu menyimpan, menjaga, dan merawat agar Protokol-Protokol tersebut tetap tersimpan dengan aman agar tidak mudah rusak dan hilang karena Protokol Notaris merupakan arsip negara yang harus tetap ada walaupun Notaris yang bersangkutan sudah tidak menjabat lagi. Hal ini dilakukan karena apabila dikemudian hari para pihak menanyakan kembali perihal aktanya tersebut yang akan dijadikan alat pembuktian, maka akta tersebut masih ada. Sehingga Notaris Penerima Protokol wajib menjalankan tanggungjawabnya dengan baik dan benar, apabila Protokol Notaris yang dipegang/disimpannya mengalami kerusakan atau kehilangan akibat kelalaiannya, maka Notaris Penerima Protokol dapat dimintai pertanggungjawaban hingga keranah pidana.

\section{Daftar Pustaka}

\section{Buku}

Adjie, Habib dan Rusdianto Sesung, Tafsir, Penjelasan dan Komentar Atas Undang-Undang Jabatan Notaris, PT. Refika Aditama, Bandung, 2020.

Amsyah, Zulkifli, Manajemen Kearsipan, Gramedia Pustaka Utama, Jakarta, 2005.

Notodisoerjo, Soegondo, Hukum Notariat di Indonesia Suatu Penjelasan, PT. Raja Grafindo Persada, Jakarta.

Sjaifurrachman \& Habib Adjie, Aspek Pertanggungjawaban Notaris dalam Pembuatan Akta, CV. Mandar Maju, Bandung, 2011.

\section{Jurnal}

Brinda Anitha Wirastuti, "Akibat Hukum Protokol Notaris Yang Tidak Diserahkan Oleh Ahli Waris Kepada Notaris Lain", Jurnal Al-Qanun, Vol. 20, No. 2, Desember, 2017. 
Cut Era Fitriyeni, "Tanggung Jawab Notaris Terhadap Penyimpanan Minuta Akta Sebagai Bagian Dari Prokol Notaris", Kanun Jurnal Hukum, Nomor 58, Desember, 2010.

Hatta Isnaini Wahyu Utomo, Imam, Safi'I, “Tanggungjawab Mantan Karyawan Notaris sebagai Saksi Akta Terhadap Kerahasiaan Akta", Jurnala Res Judicata, Vol. 2, No. 2, 2019.

Hery Sunaryanto, "Efektivitas Tempat Penyimpanan Protokol Notaris Yang Telah Berumur 25 Tahun", Jurnal Hukum dan Kenotariatan, Vol. 2 No. 2, Malang, 2018.

Melita Trisnawati, Suteki, "Perlindungan Hukum Terhadap Notaris Penerima Protokol Dalam Hal Terjadi Pelanggaran Akta Notaris Oleh Notaris Pemberi Protokol Yang Telah Meninggal", Jurnal Notarius, Vol. 12, No. 1, Semarang, 2019.

Mohamat Rizka Kuswanto, "Urgensi Penyimpanan Protokol Notaris Dalam Bentuk Elektronik Dan Kepastian Hukumnya Di Indonesia", Jurnal Repertorium, Vol. IV. No. 2. Surakarta, 2017.

\section{Peraturan Perundang-Undangan}

Undang-Undang Republik Indonesia Nomor 2 Tahun 2014 tentang Perubahan Atas Undang-Undang Nomor 30 Tahun 2004 Tentang Jabatan Notaris

Kitab Undang-Undang Hukum Perdata (KUHPerdata)

Peraturan Menteri Hukum dan Hak Asasi Manusia Republik Indonesia Nomor 40 Tahun 2015 tentang Susunan Organisasi, Tata Cara Pengangkatan Anggota, Pemberhentian Anggota, dan Tata Kerja Majelis Pengawas Notaris. 